\title{
TEBUCONAZOLE IS A NEW SUBSTANCE USED TO PROTECT SELECTED LIBRARY RESOURCES FROM ROMAN SANGUSZKI LIBRARY
}

\section{Introduction}

A group of chemicals described as 1,2,4-triazole derivatives are biologically active substances which occur as active ingredients in many fungicide formulations available in plant protection. Despite being applied through many years and incidentally having recorded the development of immunity, these preparations have been still classified as promising, that demonstrate required effectiveness in combating the threat posed by a large number of fungi.

Tebuconazole (triazoles group), which shows high fungicide efficacy and simultaneously low damage to books and other printed materials was the main substance used for this particular examination. For that reason the tebuconazole is used in fast interventions. It is also non toxic for the environment and provides no carcinogenic activity ${ }^{1}$. The mechanism of biological activity of this fungicides' group lies in their ability to inhibit the synthesis of sterolic alcohol which is called ergosetrol and is responsible for selectivity of cytomembrane ${ }^{2}$. It is broken by the lack or deficiency of sterol in the cell's environment ${ }^{3}$.

*Agnieszka Bangrowska - dr chemii; adiunkt w Zakładzie Ochrony i Konserwacji Zbiorów Bibliotecznych, Instytut Bibliotekoznawstwa, Uniwersytet Śląski w Katowicach/ Philological faculty Institute of Library Science and Information Science Laboratory of Library Collection Protection; e-mail: bakalarzadr@poczta.onet.pl

${ }^{1}$ B. Zyska, Ochrona zbiorów przed zniszczeniem, Katowice 1998, s. 122-130.

${ }^{2}$ P. Kraus, Untersuchungen zum Wirkungsmechanismus von Baycor, „Pflanzenschutz-Nachrichten Bayer"e, 12 (1976) s. 17-30.

${ }^{3}$ D. Kramer, Sterol Biosythesis and Anti-Feeding Compounds, Berlin 2004. 


\section{Assessment of biological purity object Nouveau Dictionnaire D'Histoire naturelle. A Paris AN XI-1803 from the Library of Roman Sanguszki}

The basis for the object classification for disinfection was the visual assessment of 24 the conservation status of 24 dictionary volumes from the Library of Roman Sanguszko back to 1803. The state of library preservation was good except for the volume of AN-XI, which clearly had visible traces of microbiological activities with characteristic spots and discolorations, which was the evidence for the presence of the fungal colonies. Also there were visible paper worn outs and its fragility pic.1. The remaining volumes were clean, with no stains, traces of moisture or flooding, which allowed to recognize them as objects that do not require disinfection. Volume XI was subjected to a microbiological test which also confirmed the presence of Penicillium chrysogenum. An appropriate concentration of isopropanol was drawn up for disinfection. It should be emphasized that the conservation work at such level of infection could not be carried out because it brought together the potential threat not only to other collections but also for librarians' and conservators' health.

Rys.1. Obiekt nowojorski Dictionnaire d'Histoire Naturelle.

Pic.1. Object Nouveau Dictionnaire d'Histoire Naturelle.

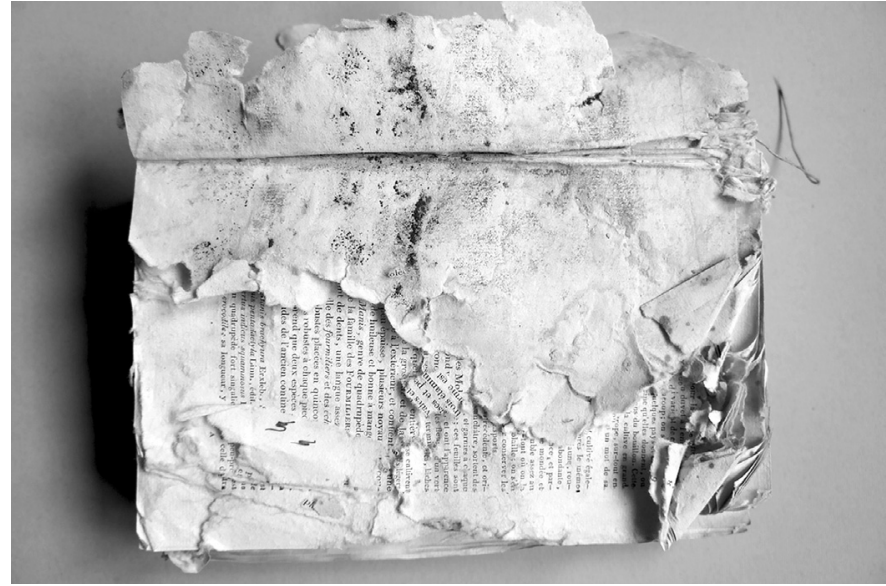

Źródto: opracowanie własne.

Source: own elaboration.

\section{Microbiological examination - part experimental}

Before taking a sample it was examined by the contact method of paper $\mathrm{pH}$, which indicated 4.6, and a number of double bends were also conducted. The paper was brittle. Microbiological examination, in turn, consisted in taking some samples with the ejector method from the most threatened places on the surface. This was done by placing a sterile filter paper $(5 \times 5 \mathrm{~cm})$, where the sample was going to be taken, then pressing it down lightly, next transferring the sample into a Petri dish of agar substrate on the wort. Petri plates with collected samples were 
incubated at room temperature for up to 14 days. The growth of microorganisms was not observed. Then the fungus type identification confirmed the presence of microscopic Penicillium chrysogenum ${ }^{4}$.

\section{Task of the study}

The main aim of this study was to carry out an initial experiment in order to check, whether triazoles could be used to fight microbiological hazards of library collections. For this particular study tebuconazole was chosen as a model example of the active substance and pathogen called Penicillium chrysogenum was the tested fungal material. The tebuconazol is a racemic solid substance, soluble in polar organic solvents, photo- and thermal stable in alcohols. The examined substance is usually obtained by reaction of 2-t-butylo-2-(4-chlorofenyloetylo)-oxirane with $1,2,4$-triazole in dimethyl sulfoxide in the presence of a base On the market it is known as Tebu $250 \mathrm{EW}$ and Horizon $250 \mathrm{EW}^{5}$.

\section{The experiment}

To relate the impact of fungicidal activity of tebuconazol on prints, which would need preservation in the library, I had to determine the ED50 factor before the right investigation. The biological activity of the fungicides was referred in the ancient book preservation process, involving the appointment of the so-called ED50 coefficients, i.e. how big amount of the substance is needed to destroy half of the fungal pathogens' population. The ED50 ratio is used to determine the concentration of active substance which should be sprayed on the surfaces of protected material: paper, parchment, leather or fabric, providing the required protective efficacy.To get the correct ratio I prepared a set of concentration series, which contained isopropanolic solutions of tebuconazol. In the next stage, these solutions, in the volume of $1 \mathrm{~cm}^{3}$, were mixed with $50 \mathrm{~cm}^{3}$ of nutrient that consisted of agar-agar solved in wort and then they were placed in Petri dish. The test material, i.e. spawns of fungus Penicillium chrysogenum, was placed nutrient was set in the range from 105 to $102 \mathrm{ng} / \mathrm{cm}^{3}$. The linear growth of the fungus was measured every $24 \mathrm{~h}$ until the tested fungus totally covered the control dish, which included the nutrient set with $1 \mathrm{~cm}^{3}$ of isopropanol ${ }^{6}$.

${ }^{4}$ O. Fasatiowa, Grzyby mikroskopowe w mikrobiologii technicznej, Warszawa 1983, s. 32.

${ }^{5}$ Kraus, Untersuchungen zum Wirkungsmechanismus von Baycor, s. 17-30.

${ }^{6}$ A. Bakalarz-Bangrowska, Wprowadzenie nowej generacji biocydów jako środków chemicznych do dezynfekcji zabytkowej kolekcji bibliotecznej, „Biblioteka Nostra”, 47 (2017) s. 114-124. 


\section{Results and discussion}

The fungicidal activity of tebuconazol on Penicillium chrysogenum is given as ED50 ratio and the results are presented below in the table 1:

Tabela1. Aktywność grzybobójcza badanej substancji

Table 1. Fungicidal activity of the test substance

\begin{tabular}{|c|c|c|c|c|c|c|}
\hline $\begin{array}{l}\text { Dosis } \\
{[\mathrm{ng} / \mathrm{cm} 3]}\end{array}$ & $\begin{array}{l}\text { Log } \\
\text { of the } \\
\text { dosis }\end{array}$ & $\begin{array}{l}\text { The medium } \\
\text { size of } \\
\text { the fungal }\end{array}$ & $\begin{array}{c}\text { Fungicidal } \\
\text { efficacy } \\
{[\%]}\end{array}$ & Probit & $\begin{array}{l}\text { The } \\
\text { mortality } \\
\text { of spawn }\end{array}$ & $\begin{array}{c}\text { Wzór wartości funkcji probit } \\
\text { dla danej w kolumnie6 } \\
\text {,=ROZKŁAD. } \\
\text { NORMALNY.S.ODW(x)+5" }\end{array}$ \\
\hline & & & & & & \\
\hline 2000 & 3,301 & 30 & 25 & 4,326 & 0,25 & 4,326 \\
\hline 4000 & 3,602 & 24 & 40 & 4,747 & 0,40 & 4,747 \\
\hline 8000 & 3,903 & 20 & 50 & 5 & 0,5 & 5 \\
\hline 16000 & 4,204 & 12,5 & 69 & 5,496 & 0,69 & 5,496 \\
\hline 32000 & 4,505 & 10 & 98 & 7,054 & 0,98 & 7,054 \\
\hline 64000 & 4,806 & - & 100 & - & - & - \\
\hline
\end{tabular}

Źródto: opracowanie własne

Source: own elaboration

The linear growth dynamics of fungal test material presents pic. 2 and it refers to tebuconazol dose in size $4 \times 10^{3} \mathrm{ng} / \mathrm{cm}^{3}$ of nutrient and the incubation period $7 \times 24 \mathrm{~h}$.

Rys. 2. Liniowy wzrost po 7 dniach inkubacji Penicillium chrysogenum

Pic. 2. The linear growth of fungus after the $7 \mathrm{~d}$. incubation period.

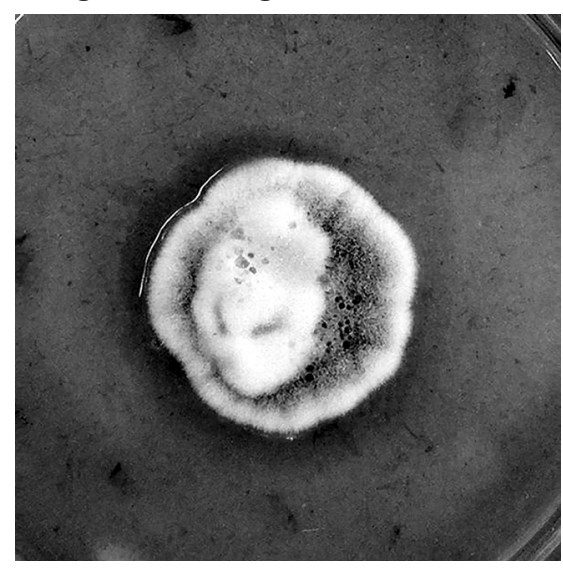

Źródto: opracowanie własne.

Source: own elaboration. 
The growth of the fungus dynamics was measured with the diameter of the growth zone in the both examined probe and control sample and was given in millimeters. Whereas the quantitative measure was set by the difference of the growth zones of the examined probe and control sample to the control sample and was given per centum. The Lietchfield and Wilcoxon ${ }^{7}$ method for simplified log-probit function was used by, extrapolating the dose from the curve at the $50 \%$ level of efficacy. The relation of tebuconazol efficacy to the used dose was drawn in the graphs 1 and 2:

Wykres 1. Zależność skuteczności działania tebukonazolu od zastosowanej dawki w teście Penicillium chrysogenum.

Graph 1. The test of Penicillium chrysogenum, the efficacy of tebuconazol depending on the dose.

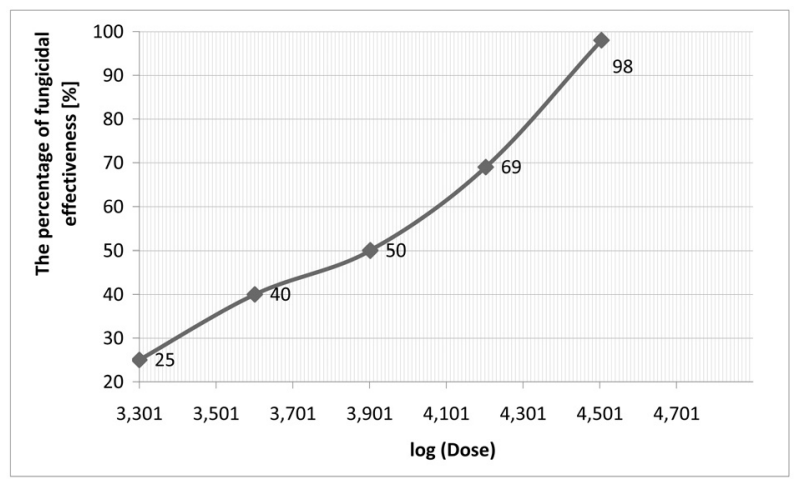

Źródto: opracowanie własne.

Source: own elaboration.

Wykres 2. Funkcja lagarytmiczno-probitowa.

Graph 2. The graph of log-probit function.

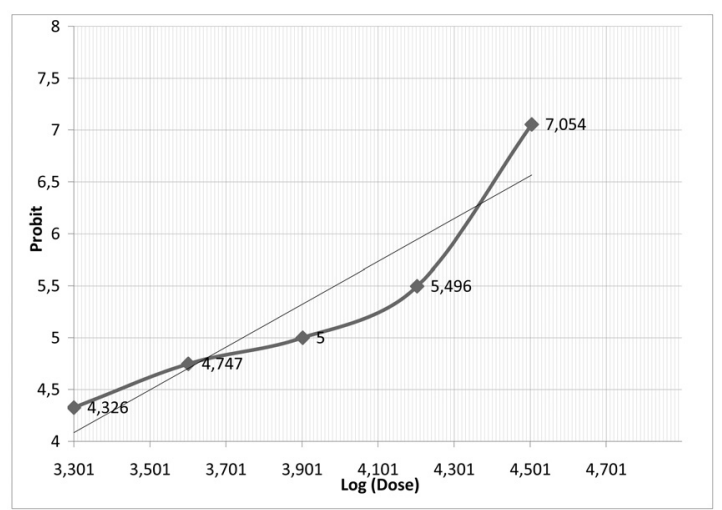

Źródło: opracowanie własne.

Source: own elaboration.

${ }^{7}$ J.T. Lietchfield, F. Wilcoxon, A simlified method of evaluating dose - effect experiments, „Journal of Pharmacology and Experimental Therapeutics”, 96 (1949) s. 99-113. 
According to the graphs presented above the size of the dose was given in logarithmic form, in which $50 \%$ of the fungal population was deceased.It amounted 3,903 what corresponded with the concentration of the substance $8,0 \times 10^{3} \mathrm{ng} / \mathrm{cm}^{3}$ of the nutrient, which was the $\mathrm{ED}_{50}$ being designated earlier. This dose of tebuconazol in $50 \mathrm{~cm}^{3}$ of the nutrient could be obtained by adding $1 \mathrm{~cm}^{3}$ of substance solved in $0,10 \%$ isopropanol to it.

\section{Disinfection}

The obtained information was the basis for further activities related to disinfection of spacers set with the method of blotting paper saturated in $0.1 \%$ isopropanol solution of tebuconazole. Spacers were placed every 20 pages. The object with the spacers was stored in hermetic foil bag at room temperature for 7 days.

\section{Result of the experiment}

After conducted disinfection I measured $\mathrm{pH}$ which amounted about 4.8. The whole collection was sent to the Library. After a month, the microbial assessment was carried out again as described above. After 14 days there was no mycelial growth or $\mathrm{pH}$ changes. Isopropanol solution of tebuconazole proved to be effective, safe for humans, the environment and a building. It is a chemical agent that should be implemented to disinfection by other research centers.

\section{Conclusion}

Isopropanol solution of tebuconazole in designated concentration is an effective disinfectant of library which is infected with various species of mycelium. This compound should play a very important role in protecting library collections. The results presented above should be treated as a foreword for further investigation on tebuconazol as a representative of tiazoles in preserving old printed materials. The interest in tebuconazol as fungicide and preservative arises not only from its biological activity, but also from its physiochemical stability. What is more, the potential metabolites of tebuconazol are not acidic, which allows to use it as disinfectant for all kinds of old prints. The further investigation should focus on examining the fungal material to a greater degree, that can confirm the level of different pathogens' sensitivity and develop the interpretation of the results with all required elements of the statistic analysis. Moreover, to describe the level of toxicological danger for the reader of the book, basing on the variety of chromatography techniques the decay time of the active substance in the paper should be noted. The research also provides chromatographic and spectroscopic testing of changes in the book under the influence of the tested product. 


\section{BIBLIOGRAPHY}

Bakalarz-Bangrowska Agnieszka, Chromatography in the study of antique book, Katowice 2013, p. 7-65.

Bakalarz-Bangrowska Agnieszka, Microbial assessment of the conservation status of the selected library collections from Jasna Góra library in Czestochowa, „Visn. L'viv. Univ., Cheese. Kn.znavstvo Bibl.znavstvo", 10 (2015) p. 64-70.

Bakalarz-Bangrowska Agnieszka, The use of tebuconazole as a fungicide to protect the library, „Visn. L'viv. Univ., Cheese. Kn.znavstvo Bibl.znavstvo”, 11 (2016) p. 54-59.

Bakalarz-Bangrowska Agnieszka, Introduction of a new generation of biocides as a disinfectant for the antique library collection, „Library Nostra”, 47 (2017) p. 114-124.

Fasatiowa Olga ,Grzyby mikroskopowe w mikrobiologii technicznej, Warszawa 1983.

Kramer Dietrich, Sterol Biosythesis and Anti-Feeding Compounds, Berlin 2004.

Kraus Peter, Untersuchungen zum Wirkungsmechanismus von Baycor, „Pflanzenschutz-Nachrichten Bayer ${ }^{\mathrm{ec}}, 12$ (1976) p. 17-30.

Lietchfield Jons, ,, A simlified method of evaluating dose - effect experiments, „Journal of Pharmacology and Experimental Therapeutics", 96 (1949) p. 99-113.

Zyska Bronisław, Ochrona zbiorów przed zniszczeniem, Katowice 1998.

\section{BIBLIOGRAFIA}

Bakalarz-Bangrowska Agnieszka, Chromatografia w badaniu książki zabytkowej, Katowice 2013, s. 7-65.

Bakalarz-Bangrowska Agnieszka, Microbial assessment of the conservation status of the selected library collections from Jasna Góra library in Czestochowa, „Visn. L'viv. Univ., Ser. Kn.znavstvo Bibl.znavstvo", 10 (2015) s. 64-70.

Bakalarz-Bangrowska Agnieszka, The use of tebuconazole as a fungicide to protect the library,„Вісник Львівського ун-ту. Серія книгозн. бібліот. та інф. Технол”, 11 (2016) s. 54-59.

Bakalarz-Bangrowska Agnieszka, Wprowadzenie nowej generacji biocydów jako środków chemicznych do dezynfekcji zabytkowej kolekcji bibliotecznej, „Biblioteka Nostra”, 47 (2017) s. 114-124.

Fasatiowa Olga,Grzyby mikroskopowe w mikrobiologii technicznej, Warszawa 1983.

Kramer Dietrich, Sterol Biosythesis and Anti-Feeding Compounds, Berlin 2004.

Kraus Peter, Untersuchungen zum Wirkungsmechanismus von Baycor, „Pflanzenschutz-Nachrichten Bayer", 12 (1976) s. 17-30.

Lietchfield Jons, A simlified method of evaluating dose - effect experiments, „Journal of Pharmacology and Experimental Therapeutics", (96) 1949, s. 99-113.

Zyska Bronisław, Ochrona zbiorów przed zniszczeniem, Katowice 1998.

Słowa kluczowe: ochrona mikrobiologiczna; grzyby; fungicydy; zbiory biblioteczne; tebukonazol; triazol 


\title{
TEBUCONAZOLE IS A NEW SUBSTANCE USED TO PROTECT SELECTED LIBRARY RESOURCES FROM ROMAN SANGUSZKI LIBRARY
}

\begin{abstract}
Summary
The protection of library collections is currently subject to a number of justified scientific studies of microbiological, chemical or physicochemical nature. Particularly microbiological processes due to the extensive and destructive effects that include irreversible changes in library collections cause the search for new substances and methods to inhibit and protect certain materials from the action of fungi and other physicochemical agents 3 . Fungicides include substances that we call fungicides fungicidal and fungal.

The basic component determining the specificity of a plant protection product used for book conservation is the substance biologically active in relation to certain organisms, i.e. which causes the disorder of the physiological processes by blocking the activity of the respective enzymes. We share them with surface-active fungicides, whose task is to block the breathing process. These include copper, sulfuric fungicides, triocarbonyl derivatives, dithiocarbamates, aromatic hydrocarbon derivatives, dicarboximide fungicides. The second group, in turn, include surface and internal fungicides. This is a systemic (systemic) action that involves the development of various pathogens and the inhibition of the destruction of the paper. These include: anilino pyrimidine, benzimidazole, phenylamides and triazole.The main aim of the study was to use tebuconazole from a number of tested triazole compounds as a novel substance to combat microbiological hazards in historic library collections. 24 volumes of dictionaries from the Library of Roman Sanguszka from 1803 were covered. Preservation of collections was good except for AN-XI volume, where there were evident traces of microbial activity, characteristic spots and discolourations, and therefore the presence of fungal colonies. In addition, paper fragments were visible. The remaining volumes were clean, without stains, traces of floods and humidities, which allowed them to be considered non-disinfection objects. Volume XI was subjected to a microbiological test which confirmed the presence of Penicilliumchrysogenum. Its mechanism of biological activity is the inhibition of ergosterol, the substance building blocks of the cell membrane. Before the right investigation, the biological activity of the fungicides was refered in the ancient book preservation process, involving the appointment of the so-called. LD50 coefficients, i.e. how amount of the substance is needed to destroy half the population of pathogens. The LD50 is used to determine the concentration of working fluid, which should be sprayed on the surfaces of the protected material: paper, parchment, leather or fabric, providing the required protective efficacy.
\end{abstract}

Keywords: conservation; fungi; fungicides; library collections; tebuconazole; triazole 


\title{
TEBUKONAZOL JAKO NOWA SUBSTANCJA ZASTOSOWANA DO OCHRONY WYBRANYCH ZASOBÓW BIBLIOTECZNYCH POCHODZĄCYCH Z BIBLIOTEKI ROMANA SANGUSZKI
}

\begin{abstract}
Streszczenie
Zagadnienia ochrony zbiorów bibliotecznych są obecnie przedmiotem wielu uzasadnionych badań naukowych o charakterze mikrobiologicznym, chemicznym lub fizykochemicznym $^{8}$. Szczególnie procesy mikrobiologiczne ze względu na rozległe i niszczące działanie, które obejmują nieodwracalne zmiany w zabytkowych kolekcjach bibliotecznych powodują poszukiwanie nowych substancji i sposobu powstrzymywania jak również zabezpieczania określonych materiałów przed działaniem grzybów i innych czynników fizykochemicznych ${ }^{9}$. Do zwalczania grzybów należą substancje, które nazywamy fungicydami o działaniu grzybobójczym i grzybostatycznym. Podstawowym składnikiem decydującym o specyfice działania środka ochrony roślin jest substancja aktywna czyli biologicznie czynna w stosunku do określonych organizmów, która powoduje zaburzenie ich procesów fizjologicznych na skutek blokowania aktywności odpowiednich enzymów. Dzielimy je na fungicydy o działaniu powierzchniowym, których zadaniem jest blokowanie procesów oddychania. Należą do nich fungicydy miedziowe, siarkowe, pochodne triokarbonylu, ditiokarbaminiany, pochodne węglowodorów aromatycznych, fungicydy dikarboksyimidowe. Do drugiej grupy z kolei należą fungicydy o działaniu powierzchniowym i wewnętrznym. Jest to działanie układowe (systemiczne), które polega na wywołaniu różnych zaburzeń rozwojowych patogenów i zahamowaniu procesu destrukcji papieru. Należą do nich związki: anilino pirymidyny, benzimidazolowe, fenyloamidy oraz triazolowe. Zasadniczym celem badań było zastosowanie tebukonazolu spośród szeregu przebadanych pochodnych związków triazolowych jako nowej substancji do zwalczania zagrożeń mikrobiologicznych w zabytkowych kolekcjach bibliotecznych. Szczególnym przedmiotem były objęte 24 tomy słowników pochodzących z Biblioteki Romana Sanguszki z 1803 r. Stan zachowania zbiorów był dobry, za wyjątkiem tomu AN-XI, gdzie było widać ślady aktywności mikrobiologicznej, charakterystyczne plamy i przebarwienia, a więc obecność kolonii grzybów. Ponadto widoczne były przedarcia papieru i jego kruchość. Pozostałe tomy były czyste, bez zacieków, śladów zalań i zawilgoceń, co pozwoliło uznać je za obiekty nie wymagające dezynfekcji. Tom XI był poddany badaniu mikrobiologicznemu co potwierdziło obecność Penicillium chrysogenum. Mechanizm biologicznej aktywności tebukonazolu polega na inhibicji ergosterolu, substancji budulcowej błony komórkowej. Aby biologiczną aktywność tebukonazolu odnieść do książki zabytkowej należy wykonać badania podstawowe, polegające na wyznaczeniu tzw. współczynników $\mathrm{LD}_{50}$, a więc dawek tych substancji dla poszczególnych patogenów, dla których połowa populacji ulega zniszczeniu. Stanowi to podstawę do wyznaczenia stężenia cieczy roboczej, zapewniającej wymaganą skuteczność ochronną, którą należy opryskać powierzchnie ochranianego materiału: papieru, pergaminu, skóry czy tkaniny.
\end{abstract}

${ }^{8}$ A. Bakalarz-Bangrowska, Chromatografia w badaniu ksiązki zabytkowej, Katowice 2013, s. 7-65; taż, Microbial assessment of the conservation status of the selected library collections from Jasna Góra library in Częstochowa „Вісник Львівського ун-ту. Серія книгозн. бібліот. та інф. Технол", 10 (2015) s. 64-70.

${ }^{9}$ Taż, The use of tebuconazole as a fungicide to protect the library, „Вісник Львівського ун-ту. Серія книгозн. бібліот. та інф. Технол”, 11 (2016) s. 54-59. 